\title{
The Evaluation of Oxidative Stress and High-Density Lipoprotein Cholesterol Levels in Diffuse Large B-Cell Lymphoma
}

\begin{abstract}
MIHNEA ALEXANDRU GAMAN ${ }^{1 *}$, MIRELA ELENA EPINGEAC ${ }^{2}$, AMELIA MARIA GAMAN ${ }^{2,3}$
${ }^{1}$ Carol Davila University of Medicine and Pharmacy, 8 Eroii Sanitari Boulevard, Bucharest 050474, Romania

2Department of Pathophysiology, University of Medicine and Pharmacy of Craiova, 2 Petru Rares Str., 200349, Craiova, Romania

${ }^{3}$ Clinic of Hematology, Filantropia City Hospital, 1 Filantropiei Str., 200143, Craiova, Romania

Diffuse large $B$-cell lymphoma (DLBCL) is the most common aggressive B-cell non-Hodgkin's lymphoma. Oxidative stress, defined as an imbalance between the levels of pro-oxidants and the antioxidant defense, is involved in lymphomagenesis via chronic inflammation and is associated with a decrease in circulating levels of high-density lipoprotein (HDL) cholesterol. We evaluated oxidative stress levels in DLBCL patients by FORT (Free Oxygen Radicals Testing) and FORD assays (Free Oxygen Radical Defense), and investigated the relationship between oxidative stress markers and $\mathrm{HDL}$-cholesterol levels. Our results suggest that oxidative stress and decreased levels of HDL-cholesterol might play a role in DLBCL pathogenesis via chronic inflammation.
\end{abstract}

Keywords: Oxidative Stress, Cholesterol, Diffuse Large B-cell Lymphoma, Non-Hodgkin's Lymphoma

Diffuse large B-cell lymphoma (DLBCL) is the most common aggressive B-cell non-Hodgkin's lymphoma (NHL). It is characterized by a marked morphological, phenotypical, clinical and outcome heterogeneity [1-2]. The most important genetic alterations in DLBCL include translocations of $B C L 6, B C L 2$ and MYC, inactivation of the tumor suppressor TP53, and aberrant somatic hypermutations involving proto-oncogenes such as PIM1, MYC and PAX5 [3]. Since DLBCL can develop from B-cells in different stages of differentiation, gene expression profiling studies have identified three molecular DLBCL subtypes: germinal center B-cell like (GCB-DLBCL), activated $B$-cell like (ABC-DLBCL) and unclassified B-cell lymphoma [4-5]. Malignant transformation follows a different pathway depending on the DLBCL subtype.

GBC-DLBCL is characterized by the $t(14 ; 18)$ translocation, which deregulates the expression of $B C L 2$, an inhibitor of apoptosis [6]. Also, mutations in the histone methyltransferase EZH2, mutations and/or deletions inactivating the acetyltransferase CREBBP genes and less frequently EP 300 , and somatic mutations affecting negative autoregulatory elements in the BCL6 promoter, with negative regulation of the DNA damage response, $B$ cell activation and differentiation, and $\mathrm{p} 53$ function, may also be found in GBC-DLBCL $[1,4]$. This subtype is also associated with miR-17-92 overexpression, a gene that cooperates with MYC to induce proliferation and growth of malignant cells by suppressing PTEN [7-8] .

$A B C-D L B C L$ is characterized by: amplifications of the $B C L 2$ locus on 18q24 (leading to altered apoptosis), mutations in CARD11, CD79B, MYD88, TNFAIP3/A20 (leading to constitutive activation of NF-kB signaling pathway which promotes cell proliferation, differentiation and suppresses apoptosis), BCR (CD79A/B) and JAK/STAT (MYD88) signaling pathways, inactivating mutations and deletions of PRDM1 (causing an altered regulation of terminal B-cell differentiation), deletion or lack of expression of the CDKN2A tumor suppressor gene, and chromosomal translocations deregulating the BCL6 oncogene [1, 3-4, 9-14] .

Even with gene expression profiling, many $D L B C L$ cases remain unclassified. In unclassified DLBCL, NOTCH2 and
SPEN mutations and BCL6 fusions significantly co-occur [5]. The revised classification of DLBCL from 2016 recognized two types of DLBCL: GCB and ABC (or non$\mathrm{GCB}$ ). Somatic mutations common in both $\mathrm{DLBCL}$ subtypes are: inactivating mutations of TP53 and genes involved in immunosurveillance (B2M, CD58), alterations in epigenetic regulators (CREBBP/EP300, KMT2D/C [MLL2/3], MEF2B), and oncogenic activation of BCL6. GCB-DLBCL cases carry frequent alterations in the histone methyltransferase $\mathrm{EZH} 2$, BCL2 translocations, and mutations in the cell motility regulator GNA13, whereas ABC-DLBCL cases exhibit mutations in genes activating the $\mathrm{B}$-cell/Toll-like receptors and NF-kB pathways [15-19].

Oxidative stress, defined as an imbalance between the levels of pro-oxidants and the antioxidant defenses of the body, is involved in lymphomagenesis via chronic inflammation. Reactive oxygen species (ROS) propagate pro-inflammatory cytokines, including interleukin-1, which stimulates B-cells to produce antibodies that initiate signaling for B-cell activation and induce oxidative damage to the DNA [20-21]. Antioxidant enzymes, including superoxide dismutase, glutathione peroxidase and catalase, ensure protection against the harmful effects of ROS. Genetic variations in the genes coding for these enzymes (SOD2, GPX1, and CAT, respectively) alter ROS production and may be involved in a mechanism which could explain the relationship between inflammation and NHL [21-22]. Patients with inflammatory diseases and NHL exhibit an abnormal lipid metabolism, characterized by decreased values of high-density lipoprotein (HDL) circulating cholesterol - and elevated values of triglycerides (TG) and elevated very low density lipoproteins (VLDL) [23]. A decrease in the circulating HDL-cholesterol may occur during lymphomagenesis, reflecting an underlying etiology such as inflammation. Spiegel et al. investigated plasma lipids and lipoproteins in patients with acute leukemia and NHL and reported low levels of HDLcholesterol and elevated TG and VLDL values. The abnormal lipid profile was directly related to the underlying tumor burden and particularly to the presence of bone marrow involvement [23]. 
Thus, we evaluated the level of oxidative stress and HDLcholesterol in DLBCL patients, seeking to find a relationship between oxidative stress markers, the total antioxidant capacity and HDL-cholesterol values.

\section{Experimental part}

We enrolled 32 DLBCL patients, hospitalized in the Hematology Clinic of Craiova (Romania) stratified by age, sex and rural/urban area of residence. Informed consent was obtained from all patients prior to enrollment, in accordance with the ethical code. Positive DLBCL diagnosis was based on lymph node biopsy with histopathological and immunohistochemical examinations. Staging was performed according to the Ann-Arbor staging classification. Patients were subjected to the following lab tests and imaging techniques: complete blood count, serum chemistry profile, serum immunoglobulins, lactate dehydrogenase, HDL-cholesterol, abdominal ultrasound or computed tomography of the chest and abdomen, electrocardiography and echocardiography. Standard treatment consisted of 6-8 cycles of CHOP (Cyclophosphamide + Anthracycline + Vincristine + Prednisone) or R-CHOP (Rituximab + CHOP).

Oxidative stress levels were evaluated at DLBCL diagnosis and at the end of therapy using a CR3000 analyzer (Callegari SpA) from a single drop of capillary blood by methods previously described [24]. Free oxygen radicals were measured by the Free Oxygen Radical Testing (FORT) assay. Normal FORT ranges are considered less or equal to $2.3 \mathrm{mmol} / \mathrm{L} \mathrm{H}_{2} \mathrm{O}_{2}$ Antioxidant status was evaluated by the Free Oxygen Radical Defense (FORD) test. Normal FORD ranges are $1.07-1.53 \mathrm{mmol} / \mathrm{L}$. Data was analyzed and a $p$-value $\leq 0.01$ was considered statistically significant.

\section{Results and discussions}

The study group had a median age of 52 years and consisted in 20 men (62.5\%) and 12 women (37.5\%), revealing a male predominance. Most patients (75\%) lived in urban areas and only $25 \%$ in rural areas. DLBCL developed de novo in 30 cases (93.75\%), the histopathological exam revealing proliferation of large cells (the nucleus was double in size compared to the size of the nucleus of a normal lymphocyte), prominent nucleoli, basophilic cytoplasm, and B-cell phenotype as immunohistochemistry showed CD20 expression in all cases of DLBCL. In 2 cases (6.25\%), DLBCL developed by transformation of follicular lymphoma. DLBCL patients were staged as IIB in five cases (15.63\%), IIIB in 19 cases (59.37\%) and IVB in eight cases (25\%). The evolution was favorable with complete remission in 24 cases $(75 \%)$, six patients ( $18.75 \%)$ had partial remission after conventional treatment, and two patients (6.25\%) had refractory disease.

DLBCL patients registered a high mean value of FORT before treatment $(3.1 \mathrm{mmol} / \mathrm{L})$ which significantly decreased after specific treatment $(1.8 \mathrm{mmol} / \mathrm{L}, \mathrm{p}<0.001)$. The mean FORD value was low at diagnosis $(0.6 \mathrm{mmol} / \mathrm{L})$ and notably increased after specific treatment and a favorable evolution of the disease $(1.3 \mathrm{mmol} / \mathrm{L}, \mathrm{p}<0.001)$.

With respect to DLBCL stage, mean FORT values before treatment were: $2.48 \mathrm{mmol} / \mathrm{L}$ for stage IIB, $3.07 \mathrm{mmol} / \mathrm{L}$ for stage IIIB, and $3.63 \mathrm{mmol} / \mathrm{L}$ for stage IVB. After treatment, mean FORT value decreased to $1.14 \mathrm{mmol} / \mathrm{L}$ in stage IIB cases, to $1.66 \mathrm{mmol} / \mathrm{L}$ in stage IIIB cases, and to $2.38 \mathrm{mmol} / \mathrm{L}$ in stage IVB cases. Mean FORD values before treatment were: stage $I I B=1.01 \mathrm{mmol} / \mathrm{L}$, stage $\mathrm{IIIB}=$ $0.64 \mathrm{mmol} / \mathrm{L}$, and stage IVB $=0.29 \mathrm{mmol} / \mathrm{L}$. After treatment, mean FORD values increased to $1.49 \mathrm{mmol} / \mathrm{L}$ in stage IIB cases, to $1.38 \mathrm{mmol} / \mathrm{L}$ in stage IIIB cases, and to $0.99 \mathrm{mmol} / \mathrm{L}$ in stage IVB cases. These results are depicted in figure 1 and figure 2 .

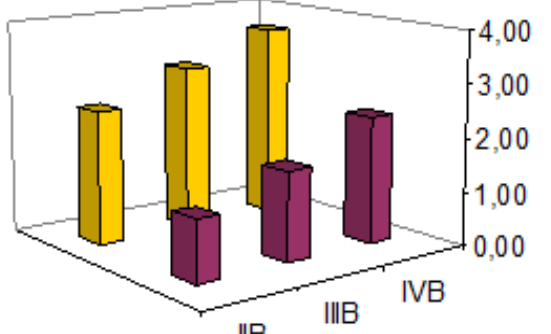

口 FORT after tre atment [mmol/L] $\square$ FORT before treatment [mmol/L]

Fig. 1. Evolution of FORT values before and after treatment

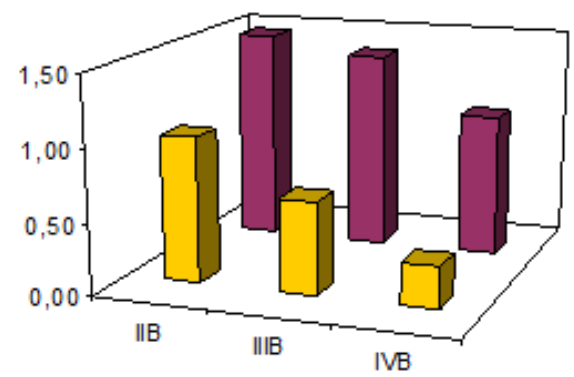

DFORD before treatment [mmoVL] GFORD a fter treatment [mmoVL]

Fig. 2. Evolution of FORD values before and after treatment

After treatment, FORT values remained high and FORD and $\mathrm{HDL}$ values remained low in the two cases of refractory disease. HDL values (normal $>60 \mathrm{mg} / \mathrm{dL}$ ) were normal in nine patients ( $28.13 \%)$, five $(55.55 \%)$ having DLBCL stage IIB and four (44.45\%) having DLBCL stage IIIB. However, the values were decreased in 23 patients prior to therapy commencement (mean value of $47 \mathrm{mg} / \mathrm{dL}$ ). The mean $\mathrm{HDL}$ value significantly increased after treatment at $65 \mathrm{mg} /$ $\mathrm{dL}(p<0.001)$. Mean HDL values before treatment according to DLBCL stage were: $67 \mathrm{mg} / \mathrm{dL}$ in stage IIB, $47.53 \mathrm{mg} / \mathrm{dL}$ in stage IIIB, and $32.5 \mathrm{mg} / \mathrm{dL}$ in stage IVB. These values increased after specific DLBCL treatment to $78 \mathrm{mg} / \mathrm{dL}$ for patients in stage IIB, to $66 \mathrm{mg} / \mathrm{dL}$ for patients in stage IIIB and to $53.75 \mathrm{mg} / \mathrm{dL}$ for patients in stage IVB. These findings are portrayed in figure 3.

Evolution of HDL before and after treatment

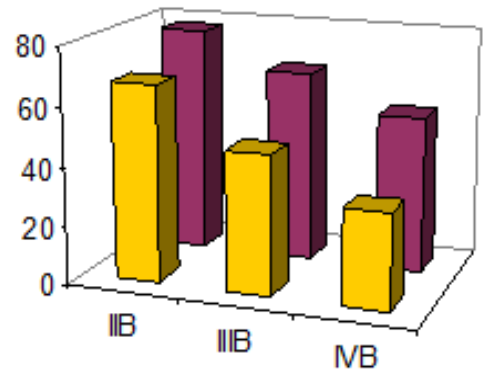

$\square \mathrm{HDL}$ before treatment [mg/dL] $\square \mathrm{HDL}$ after treatment [mg/dL]

Fig. 3. Evolution of HDL-cholesterol values before and after treatment

DLBCL is an aggressive lymphoma that can occur de novo or by transformation of a less aggressive B-NHL, such as follicular lymphoma [25]. In peculiar cases, it might even co-exist with or develop after a previous malignancy, such as chronic myeloid leukemia [26]. The genesis of lymphoma has yet to be explained. NHL risk has been associated with bacterial and viral infections and chronic 
inflammation. Infections contribute to lymphomagenesis by subverting the host cell molecular signaling pathways to deregulate cell growth and survival. Sustained antigenic stimulation triggers inflammatory responses by attracting neutrophils which, in an activated state, release ROS [27]. ROS and other free radicals can generate pro-inflammatory cytokines, including interleukin-1, which stimulates B-cells to produce antibodies that initiate signaling for B-cell activation and induce oxidative damage to all components of the cell (i.e. proteins, lipids, and DNA) [21]. DNA damage may be due to the intrinsic genetic instability of B-cells and to the activation of NF-kB, a key transcription factor which regulates the expression of several genes involved in $B$ cell survival and proliferation [28]. Lightfoot et al. analyzed genetic variation in SOD2, GPX1 and CAT (genes coding for antioxidant enzymes) in two lymphoma case-control studies, suggesting a possible role for oxidative stress in the risk for NHL in the context of inflammation [21]. In a large multicenter case-control study, Wang et al. genotyped 13 single nucleotide polymorphisms from 10 oxidative stress genes (AKR1A1, AKR1C1, CYBA, GPX, MPO, NOS2A, NOS3, OGG1, PPARG and SOD2) to determine whether these genes influence the risk for NHL, and reported that genetic variations that result in an increased generation of ROS seem to increase the risk for NHL and its major subtypes, particularly DLBCL [29]. Moreover, the overexpression of glutathione peroxidase 4 (GPX4) in DLBCL, as pointed out by Kinowaki et al., is associated with a poor prognosis, since it prevents ROS-mediated cell death [30].

In our study, all patients had at diagnosis high FORT values $(2.4-3.8 \mathrm{mmol} / \mathrm{L})$ and low FORD values $(0.21$ $1.03 \mathrm{mmol} / \mathrm{L})$. The mean value of FORT in advanced stages of DLBCL was higher ( $3.63 \mathrm{mmol} / \mathrm{L})$, almost one third compared to the mean value of FORT in the initial stages of disease $(2.48 \mathrm{mmol} / \mathrm{L})$, probably due to the tumor mass, bone marrow involvement, and the fact that malignant lymphocytes abundantly produce ROS. These values were accompanied by lower mean FORD values before treatment, especially in the DLBCL stage IVB $(0.29 \mathrm{mmol} /$ L) compared to stage IIB (1.01 mmol/L), as antioxidant systems try to neutralize ROS and protect cells from ROSinduced damage. Several studies reported that manganese superoxide dismutase (MnSOD), a primary antioxidant, plays a critical role in protecting cells from free radicals and oxidative damage, modulating apoptosis and suppressing tumorigenesis, and that, in lymphoma tumors, MnSOD activity is low [31-34]. After specific treatment, when the tumor mass and the number of malignant lymphocytes decrease, the mean FORT value, reflecting the production of ROS, decreased in DLBCL patients and the mean FORD value significantly increased.

On the other hand, Growder et al. reported that a decrease in circulating HDL-cholesterol may occur during lymphomagenesis [35]. HDL-cholesterol seems to have an anti-inflammatory role by suppressing the chemotactic activity of monocytes and lymphocytes and inhibiting the cytokine-induced expression of endothelial cell adhesion molecules, and also antioxidant properties, protecting lymphocytes from oxidative damage [36-40]. Clinical studies that investigated plasma lipids and lipoproteins in lymphoma patients reported lipid abnormalities directly related to the underlying tumor burden and to the presence of bone marrow involvement, and a decrease in circulating HDL-cholesterol, reflecting an underlying etiology such as inflammation during lymphomagenesis $[23,41]$.

In our study, the mean value of HDL-cholesterol was decreased especially in advanced DLBCL stages, probably related to a higher degree of chronic inflammation and oxidative stress, and increased significantly after specific treatment, in relation to a reduced degree of inflammation, diminished release of pro-inflammatory cytokines and production of free radicals, and a reduced volume of malignant cells. Lim et al. investigated the association between the pre-diagnostic serum HDL-cholesterol levels and the subsequent development of NHL during 17 years of follow-up, observing an inverse association between HDL-cholesterol levels and NHL during the first 10 years, which changed with the length of the follow-up [42]. Taking this data into account, low HDL-cholesterol may be a marker for the severity of systemic inflammation and inflammation-induced NHL risk, or may be a parameter with potential prognosis impact in DLBCL [43]. Also, some natural products with hypolipidemic and antioxidant properties could serve as potential oxidative stresslowering molecules in DLBCL and other cancers, but it is too early to assess their applicability in the clinical ward [44-45]. Nevertheless, oxidative stress has emerged as a putative mechanism in the development of a myriad of diseases, not only cancer: heart failure, arterial hypertension, obesity, neurodegenerative disorders or type 2 diabetes mellitus are just some common examples [38, 46-48].

\section{Conclusions}

The results of our study suggest a possible association between oxidative stress and advanced DLBCL stages. It is still questionable whether chronic inflammation reduces HDL-cholesterol levels or whether low HDL-levels predispose to chronic inflammation and an increased risk of inflammation-induced NHL. We propose a follow-up of at least 10 years of these patients with DLBCL and a periodical evaluation of the level of HDL-cholesterol and oxidative status, as well as an investigation whether any changes in these parameters are correlated with a possible DLBCL relapse.

\section{References}

1.PASQUALUCCI, L., Haematol. Educ., 5, nr. 1, 2011, p. 191.

2.GAMAN, A., BOLD, A., GAMAN, G., Rom. J. Morphol. Embryol., 52, nr. 2, 2011, p. 719.

3.HARTMANN, E., ROSENWALD, A., Haematol. Educ., 3, nr. 1, 2009, p. 106.

4.LENZ, G., Haematol. Educ., 4, nr. 1, 2010, p. 113.

5.SCHMITZ, R., WRIGHT, G. W., HUANG, D. W., JOHNSON, C. A., PHELAN, J. D., WANG, J. Q., ROULLAND. S., KASBEKAR, M., YOUNG, R. M., SHAFFER, A. L., HODSON, D. J., XIAO, W., YU, X., YANG, Y., ZHAO, H., XU, W., LIU, X., ZHOU, B., DU, W., CHAN, W. C., JAFFE, E. S., GASCOYNE, R. D., CONNORS, J. M., CAMPO, E., LOPEZGUILLERMO, A., ROSENWALD, A., OTT, G., DELABIE, J., RIMSZA, L. M., TAY KUANG WEI, K., ZELENETZ, A. D., LEONARD, J. P., BARTLETT, N. L., TRAN, B., SHETTY, J., ZHAO, Y., SOPPET, D. R., PITTALUGA, S., WILSON, W. H., STAUDT, L. M., N. Engl. J. Med., 378, nr. 15, 2018, p. 1396.

6.LENZ, G., WRIGHT, G. W., EMRE, N. C. T., KOHLHAMMER, H., DAVE, S. S., DAVIS, R. E., CARTY, S., LAM, L. T., SHAFFER, A. L., XIAO, W., POWELL, J., ROSENWALD, A., OTT, G., MULLER-HERMELINK, H. K., GASCOYNE, R. D., CONNORS, J. M., CAMPO, E., JAFFE, E. S., DELABIE, J., SMELAND, E. B., RIMSZA, L. M., FISHER, R. I., WEISENBURGER, D. D., CHAN, W.C., STAUDT, L., M., Proc. Natl. Acad. Sci. U. S. A., 105, nr. 36, 2008, p. 13520.

7.0'DONNELL, K. A., WENTZEL, E. A., ZELLER, K. I., DANG, C. V., MENDELL, J.T., Nature, 435, nr. 7043, 2005, p. 839.

8.XIAO, C., SRINIVASAN, L., CALADO, D. P., PATTERSON, H. C., ZHANG, B., WANG, J., HENDERSON, J. M., KUTOK, J. L., RAJ EWSKY, K., Nat. Immunol., 9, nr. 4, 2008, p. 405. 
9.IQBAL, J., NEPPALLI, V. T., WRIGHT, G., DAVE, B. J., HORSMAN, D. E., ROSENWALD, A., LYNCH, J., HANS, C. P., WEISENBURGER, D. D., GREINER, T. C., GASCOYNE, R. D., CAMPO, E., OTT, G., MÜLLERHERMELINK, H. K., DELABIE, J.,J AFFE, E. S., GROGAN, T. M., CONNORS, J. M., VOSE, J. M., ARMITAGE, J. O., STAUDT, L. M., CHAN, W. C., J. Clin. Oncol., 24, nr. 6, 2006, p. 961.

10.COMPAGNO, M., LIM, W. K., GRUNN, A., NANDULA, S. V., BRAHMACHARY, M., SHEN, Q., BERTONI, F., PONZONI, M., SCANDURRA, M., CALIFANO, A., BHAGAT, G., CHADBURN, A., DALLAFAVERA, R., PASQUALUCCI L., Nature, 459, nr. 7247, 2009, p. 717.

11.DAVIS, R. E., NGO, V. N., LENZ, G., TOLAR, P., YOUNG, R. M., ROMESSER, P. B., KOHLHAMMER, H., LAMY, L., ZHAO, H., YANG, Y., XU, W., PIERCE, S. K., STAUDT, L. M., Nature, 463, nr. 7277, 2010, p. 88. 12.PASQUALUCCI, L., COMPAGNO, M., HOULDSWORTH, J., MONTI, S., GRUNN, A., NANDULA, S.V., ASTER, J. C., MURTY, V. V., SHIPP, M. A, DALLA-FAVERA, R., J. Exp. Med., 203, nr. 2, 2006, p. 311.

13.TAM, W., GOMEZ, M., CHADBURN, A., LEE, J. W., CHAN, W. C., KNOWLES, D. M., Blood, 107, nr. 10, 2006, p. 4090.

14.MANDELBAUM, J., BHAGAT, G., TANG, H., MO, T., BRAHMACHARY, M., SHEN, Q., CHADBURN, A., RAJEWSKY, K., TARAKHOVSKY, A., PASQUALUCCI, L., DALLA-FAVERA, R., Cancer Cell, 18, nr. 6, 2010, p. 568.

15.SWERDLOW, S. H., CAMPO, E., PILERI, S. A., HARRIS, N. L., STEIN, H., SIEBERT, R., ADVANI, R., GHIELMINI, M., SALLES, G. A., ZELENETZ, A. D., JAFFE, E. S., Blood, 127, nr. 20, 2016, p. 2375.

16.J OOS, S., KÜPPER, M., OHL, S., VON BONIN, F., MECHTERSHEIMER, G., BENTZ, M., MARYNEN, P., MOLLER, P., PFREUNDSCHUH, M., TRUMPER, L., LICHTER, P., Cancer Res., 60, nr. 3, 2000, p. 549.

17.MESTRE, C., RUBIO-MOSCARDO, F., ROSENWALD, A., CLIMENT, J., DYER, M. J., STAUDT, L., PINKEL, D., SIEBERT, R., MARTINEZCLIMENT, J. A., Leukemia, 19, nr. 6, 2005, p. 1082.

18.MELZNER, I., BUCUR, A. J., BRÜDERLEIN, S., DORSCH, K., HASEL, C., BARTH, T. F., LEITHÄUSER, F., MÖLLER, P., Blood, 105, nr. 6, 2005, p. 2535.

19.SCHMITZ, R., HANSMANN, M. L., BOHLE, V., MARTIN-SUBERO, J. I., HARTMANN, S., MECHTERSHEIMER, G., KLAPPER, W., VATER, I., GIEFING, M., GESK, S., STANELLE, J., SIEBERT, R., KUPPERS R., J. Exp. Med., 206, nr. 5, 2009, p. 981.

20.GAMAN, A.M., UZONI, A., POPA-WAGNER., A., ANDREI, A., PETCU, E. B., Aging Dis., 7, nr. 3, 2015, p. 307.

21.LIGHTFOOT, T. J., SKIBOLA, C. F., SMITH, A. G., FORREST, M. S., ADAMSON, P. J., MORGAN, G. J., BRACCI, P. M., ROMAN, E., SMITH, M. T., HOLLY, E. A., Haematologica, 91, nr. 9, 2006, p. 1222.

22.WISEMAN, H., HALLIWELL, B., Biochem. J., 313, nr. 1, 1996, p. 17. 23.SPIEGEL, R. J, SCHAEFER, E. J., MAGRATH, I. T., EDWARDS, B.K., Am. J. Med., 72, nr. 5, 1982, p. 775.

24.GAMAN, A. M., BUGA, A. M., GAMAN, M. A., POPA-WAGNER, A., Oxid. Med. Cell. Longev., 2014, nr. 2014, 2014, p. 158135. doi: 10.1155/ 2014/158135.

25.GAMAN, A. M., Rom. J. Morphol. Embryol., 54, nr. 1, 2013, p. 71. 26.GAMAN, A. M., DOBREA, C., ROTARU, I., Rom. J. Morphol. Embryol., 54, nr. 4, 2013, p. 1141.

27.ZINZANI, P.L., Hematology Am. Soc. Hematol. Educ. Program., 2012, nr. 1, 2012, p. 426.

28.SIEBENLIST, U., BROWN, K., CLAUDIO, E., Nat. Rev. Immunol., 5, nr. 6, 2005, p. 435.
29.WANG SS., DAVIS S., CERHAN JR., HARTGE P., SEVERSON RK., COZEN W., LAN Q., WELCH R., CHANOCK SJ ., ROTHMAN N., Carcinogenesis, 27, nr. 9, 2006, p. 1828.

30.KINOWAKI, Y., KURATA, M., ISHIBASHI, S., IKEDA, M., TATSUZAWA, A., YAMAMOTO, M., MIURA, O., KITAGAWA, M., YAMAMOTO, K., Lab. Invest., 98, nr. 5, 2018, p. 609.

31.BEWICK, M., COUTIE, W., TUDHOPE, G. R., Br. J. Haematol., 65, nr. 3, 1987, p. 347.

32.ABDEL-AZIZ, A. F., EL NAGGAR, M. M., Cancer Lett., 113, nr. 1-2, 1997, p. 61.

33.LI, H., KANTOFF, P. W., GIOVANNUCCI, E., LEITZMANN, M. F., GAZIANO, J. M., STAMPFER, M. J., MA, J., Cancer Res., 65, nr. 6, 2005, p. 2498.

34.SURESH, A., GUEDEZ, L., MOREB, J., ZUCALI, J., Br. J. Haematol., 120, nr. 3, 2003, p. 457.

35.MCGROWDER, D., RILEY, C., MORRISON, E. Y., GORDON, L., Cholesterol, 2011, nr. 7247, 2011, p. 496925.

36.SPIEKER, L. E., RUSCHITZKA, F., LUSCHER, T.F., Curr. Drug. Targets Immune Endocr. Metabol. Disord., 4, nr. 1, 2004, p. 51.

37.COCKERILL, G. W., HUEHNS, T. Y., WEERASINGHE, A., STOCKER, C., LERCH, P. G., MILLER, N. E., HASKARD, D.O., Circulation., 103, nr. 1, 2001, p. 108.

38.PADURARU, C. F., FILIP, N., TRIFAN, A., MIRON, S. D., BADESCU, C., COSTACHE, I. I., AL NAMAT, R., DIACONESCU, B., DUMITRESCU, N., CIOCOIU, M., Rev. Chim. (Bucharest), 69, nr. 7, 2018, p. 1718. 39.LEWIS, G. F., RADER, D. J., Circ. Res., 96, nr. 12, 2005, p. 1221. 40.ANSELL, B. J., WATSON, K. E., FOGELMAN, A. M., NAVAB, M., FONAROW, G. C., J. Am. Coll. Cardiol., 46, nr. 10, 2005, p. 1792.

41.BLACKMAN, J. D., CABANA, V. G., MAZZONE, T., J. Intern. Med., 233, nr. 2, 1993, p. 201.

42.LIM, U., GAYLES, T., KATKI, H. A., STOLZENBERG-SOLOMON, R., WEINSTEIN, S. J., PIETINEN, P., TAYLOR, P. R., VIRTAMO, J., ALBANES, D., Cancer Res., 67, nr. 11, 2007, p. 5569.

43.ROTARU, I., GAMAN, G. D., STANESCU, C., GAMAN, A. M., Rom. J. Morphol. Embryol., 55, nr. 1, 2011, p. 15.

44.CHIS, I. C., BALTARU, D., CLICHICI, S., ONIGA, 0., COJOCARU, I., NASTASA, C., Rev. Chim. (Bucharest), 69, nr. 9, 2018, p. 2361.

45.ISLAM, M. T., ALI, E. S., UDDIN, S. J., ISLAM, M. A., SHAW, S., KHAN, I. N., SARAVI, S. S. S., AHMAD, S., REHMAN, S., GUPTA, V. K., GAMAN, M. A., GAMAN, A. M., YELE, S., DAS, A. K., DE CASTRO E SOUSA, J. M., DE MOURA DANTAS, S. M. M., ROLIM, H. M. L., DE CARVALHO MELOCAVALCANTE, A. A., MUBARAK, M. S., YARLA, N. S., SHILPI, J. A., MISHRA, S. K., ATANASOV, A. G., KAMAL, M.A., Cancer Lett., 420, nr. 2018, 2018, p. 129.

46.MOISA, C., GAMAN, M. A., PASCU, E. G., DRAGUSIN, O. C., ASSANI, D. A., EPINGEAC, M. E., GAMAN, A. M., Arch. Balk. Med. Union, 53, nr. 1, 2018, p. 70.

47.LUIS GOMES, A., DIMITROVA TCHEKALAROVA, J ., ATANASOVA, M., DA CONCEICAO MACHADO, K., DE SOUSA RIOS, M. A., PAZ, M. F. C. J ., GAMAN, M. A., GAMAN, A. M., YELE, S., SHILL, M. C., KHAN, I. N., ISLAM, M. A., ALI, E. S., MISHRA, S. K., ISLAM. M. T., MUBARAK, M. S., DA SILVA LOPES, L., DE CARVALHO MELO-CAVALCANTE, A. A., Biomed. Pharmacother., 106, nr. 2018, 2018, p. 1686.

48.MANEA, M., MARCU, D., PANTEA STOIAN, A., GAMAN, M. A., GAMAN, A. M., SOCEA, B., NEAGU, T. P., STANESCU, A. M. A., BRATU, O. G., DIACONU, C. C., Rev. Chim. (Bucharest), 69, nr. 11, 2018, p. 4180.

Manuscript received: 3.08 .2018 